\title{
GEOMETRY AND DENSITY OF DRIFTS FORMED BY SNOW FENGES
}

\author{
By Ronald D. TABleR
}

(Rocky Mountain Forest and Range Experiment Station, U.S. Department of Agriculture Forest Service, Laramie, Wyoming 82070 , U.S.A.)

\begin{abstract}
Aвstract. This paper presents results from studies of snow-drifts formed by vertical-slat "Canadian" and horizontal-slat "Wyoming" snow fences having $50 \%$ porosity and heights $H$ from 0.8 to $3.8 \mathrm{~m}$, on nearly level terrain. Characteristics of equilibrium lee drifts behind the Wyoming fence include cross-sectional area $19.3 H^{2}$, length $30 H$, maximum depth ${ }_{1.20}$. and water-equivalent volume $6.8 H^{2.18}$. Up-wind drift dimensions include maximum depth $0.5 \mathrm{H}$ and length 1 $2 H_{2}$. Drifts behind Canadian fences are about $25 \%$ smaller than for the Wyoming design. Polynomial regression equations are fitted to drift profiles for both fence types. Relationships are presented for the effects of wind orientation and curvature of drifts near fence ends, as well as empirical equations describing pre-equilibrium geometry relative to degree of saturation. Mean density $\rho\left(\mathrm{kg} / \mathrm{m}^{3}\right)$ of drifted snow having depth $y(\mathrm{~m})$, is given by $\rho=376+\mathrm{I} 5^{8} \log y$.

RÉsumé. Géométrie et densité des congères formées par les barrières à neige. Ce papier présente les résultats d'études des congères formées par des barrières à neige à éléments verticaux ("Canadiennes") ou horizontaux ("Wyoming") ayant une porosité de $50 \%$ et des hauteurs $H$ de 0,80 à 3,80 m sur un terrain presque horizontal. Les caractéristiques de la congère en équilibre derrière une barrière "Wyoming" sont une surface de section transversale de $19,3 \mathrm{H}^{2}$, une longeur de $30 H$, une épaisseur maximum de $1,20 H$ et un volume d'équivalent en eau de $6,8 H^{2,18}$. La congère côté au vent a une épaisseur maximum de o, $5 H$ et une longueur de $12 \mathrm{~m}$. Les congères formées par les barrières "Canadiennes" sont environ $25 \%$ plus petites que celles de géométrie "Wyoming". On a construit des équations de regression polynomiales pour les profils des congères pour les deux types de barrières. Des relations sont proposées pour caractériser les effets de la direction du vent et pour la courbure de la congère près de l'extrémité de la barrière ainsi que des équations empiriques pour décrire la géométrie du pré-équilibre relatif au degré de saturation. La densité moyenne $\rho\left(\mathrm{kg} / \mathrm{m}^{3}\right)$ de la neige soufflée de profondeur $y(\mathrm{~m})$ est donnée par $\rho=376+{ }_{1} 58 \log y$.

Zusammenfassung. Geometrie und Dichte von Driftablagerungen an Schneezäunen. Die Arbeit legt Ergebnisse aus Studien der Driftablagerungen vor, die an Schneezäunen mit vertikalen ("Kanadischer" Typ) und horizontalen ("Wyoming"-Typ) Stäben bei 50\% Durchlässigkeit und Höhen $H$ zwischen o,8 und 3,8 m auf nahezu ebenem Gelände entstanden. Zu den Charakteristiken der Gleichgewichtsdrift im Lee der "Wyoming"-Zäune gehören eine Querschnittsfläche von $19,3 \mathrm{H}^{2}$, eine Länge von $30 H$, eine Tiefe von $\mathrm{r}, 20 H$ und ein Volumen von $6,8 H^{2,18}$ Wassergehalt. Die maximalen Driftdimensionen im Luv sind $o, 5 H$ an Tiefe und ${ }_{12} \mathrm{H}$ an Länge. Driftablagerungen hinter "Kanadischen" Zäunen sind etwa 25\% kleiner als beim "Wyoming"-Typ. Für die Driftprofile beider Zauntypen werden polynomiale Regressionsgleichungen angesetzt. Für den Einfluss der Windrichtung und für die Krümmung der Driftablagerung nahe den Zaunenden werden Beziehungen abgeleitet, ebenso empirische Gleichungen zur Beschreibung der Geometrie vor der Gleichgewichtslage in Abhängigkeit vom Grad der Sättigung. Die mittlere Dichte $\rho\left(\mathrm{kg} / \mathrm{m}^{3}\right)$ des Driftschnees von der Tiefe $y(\mathrm{~m})$ folgt der Beziehung $\rho=376+15^{8} \log y$.
\end{abstract}

\section{INTRODUCTION}

Renewed interest in snow fences for the protection of transportation facilities and other structures from snow-drifts has resulted from the success of the recently constructed snow-fence system along Interstate Highway 80 in south-eastern Wyoming (Tabler, [1973]).

If snow fences are to be successful, they must be designed with sufficient capacity to store the volume of snow transported over the course of a season as estimated by currently available methods (Tabler, 1975; Komarov, I954[a]). This requires that the maximum storage capacity of fences be known. Knowledge of the relationship between fence height and storage capacity is also required before economic analyses can be used to determine optimum barrier arrangements. Analysis of fence construction costs per unit volume of snow storage, for example, clearly demonstrates tall fences to be more economical than shorter ones (Tabler, I974).

The shape of drifts behind snow fences must also be known if fences are to be properly positioned. Maximum drift length determines the minimum distance a fence should be placed up-wind of the protected area, as well as proper spacing between multiple rows of fencing. 
Detailed information on drift geometry is also essential to provide verification or calibration of wind-tunnel and water-flume simulations of snow-transport phenomena, as recently exemplified by Wuebben (1978), and to provide a basis for a better understanding of the aerodynamics of snow fences, leading to improved design.

Numerous studies have been made of air flow behind artificial and natural barriers without snow-drifts, but unfortunately it is not yet possible to infer from this information the shape which a snow-drift will assume.

By comparison very few studies have been made of the drifts themselves. It is apparent from reviews by Schneider (1959) and Mellor (1965) that no general consensus exists as to how drift characteristics are related to barrier geometry. One reason for the diversity of published results is the different experimental methods that have been used. Finney (I934) and Nøkkentved (Pugh, I950) used sawdust or mica to simulate drifts behind model barriers in wind tunnels. Although this classic work has provided many useful qualitative guidelines, it is likely that requirements for dynamic similarity were not met sufficiently to provide true geometric scaling of model and prototype.

Results of full-scale studies by Nøkkentved (Pugh, 1950), Komarov (1954[b]), Price (196r), and Croce (Mellor, I965) also provide conflicting results, probably because some investigators mistakenly identified immature drifts as having reached equilibrium. Other causes of disparate results include possible local terrain effects, and differences in weather conditions. Although there is no a priori reason why drift shapes should depend on wind speed over the relatively narrow range encountered naturally, many climatic and site factors affect the quantity of snow transport at a site, which in turn determines the likelihood of equilibrium conditions being attained.

Observations are required over many years and at numerous locations before maximum drift profiles can be known with any certainty. In addition, a wider range of heights should be studied than has been reported in the literature before the effect of height on drift geometry can be specified.

This paper presents results from extensive measurements of snow-drifts formed by horizontal- and vertical-slat snow fences having $50 \%$ porosity and heights from 0.8 to $3.8 \mathrm{~m}$. These data, collected from 1962 to 1979 at more than 60 separate locations in south-east Wyoming, allow the most definitive assessment yet available of the geometry of drifts formed by snow fences.

\section{Fence design, Study SITES, AND MEASUREMENTS}

\section{Horizontal-slat fences}

The horizontal-slat "Wyoming" fences were of the standard design used since I97 I by the Wyoming State Highway Department, as described by Tabler (r974). These structures consist of horizontal boards $15 \mathrm{~cm}$ wide separated by ${ }_{5} 5 \mathrm{~cm}$ spaces, a bottom gap of approximately o. I $H$ (where $H$ is vertical fence height), and a $15^{\circ}$ inclination down-wind. Net porosity (open area) of the structure, excluding the bottom gap, is $48 \%$, but averages about $50 \%$ over the total height.

The study fences are located along $70 \mathrm{~km}$ of Interstate Highway 80 between Laramie and Walcott, Wyoming, at elevations from 2 I 90 to $2400 \mathrm{~m}$. Of the $50 \mathrm{~km}$ of snow fence comprising the total system, $71 \%$ is $3.78 \mathrm{~m}$ in height, $6 \%$ is $3.17 \mathrm{~m}, 22 \%$ is $2.44 \mathrm{~m}$, and $\mathrm{I} \%$ is I. $83 \mathrm{~m}$ in height. Lengths of the individual fences measured for this study range from 40 to $200 H$.

The snow-drifting season typically extends from I November to I April, without appreciable melting. Average weather conditions during drifting, as measured at $2 \mathrm{~m}$ height over the $197 \mathrm{I}-72$ winter and weighted according to mass flux, were as follows: $16 \mathrm{~m} / \mathrm{s}$ wind speed 
at $260^{\circ}$ azimuth, $80 \%$ relative humidity, $-8^{\circ} \mathrm{C}$ air temperature, and $67.2 \mathrm{~J} / \mathrm{cm}^{2} \mathrm{~h}$ incoming shortwave radiation (Tabler, unpublished).

Precipitation (water-equivalent) over the accumulation season averages about $250 \mathrm{~mm}$, and the maximum recorded over the period of study ( 197 I to 1979 ) was $350 \mathrm{~mm}$.

Measurements presented here are restricted to sites on gently sloping $(<5 \%)$, uniform terrain. Contributing distance, or "fetch", extends $2-6 \mathrm{~km}$ up-wind of the study fences. Vegetation consists of low-growing $(<30 \mathrm{~cm})$ shrubs and grasses. The seasonal snow transport coefficient defined by Komarov (1954[a]) ranges from about 0.5 to 0.75 , which compares to the same author's value of 0.7 for Siberia.

\section{Vertical-slat fences}

Vertical-slat fences were of the typical wood lath and twisted wire construction, referred to by Pugh (1950, p. 4) as "Canadian" fencing. Typical dimensions included slats $3.8 \mathrm{~cm}$ wide, spaced at $5.5 \mathrm{~cm}$, resulting in a porosity of about $59 \%$. These fences were installed vertically, with a $15 \mathrm{~cm}$ bottom gap. Fence heights of $0.8,1.37, \mathrm{I} .83,2.44,3.05,3.66$, and $4.88 \mathrm{~m}$ were studied, but equilibrium drifts were only observed for the $0.8, \mathrm{I} .37$, and $3.05 \mathrm{~m}$ heights.

The $0.8 \mathrm{~m}$ fences were installed at two of the sites described for the horizontal-slat fence studies. The single $3.0 \mathrm{~m}$ fence to attain equilibrium was part of a water yield-improvement project at lat. $4 \mathrm{I}^{\circ} 59^{\prime} \mathrm{N}$., long. $105^{\circ} 3 \mathrm{O}^{\prime} \mathrm{W}$., elevation $2235 \mathrm{~m}$. All other vertical-slat fences were installed within a $3 \mathrm{~km}$ radius of lat. $41^{\circ} 16^{\prime} \mathrm{N}$., long. $105^{\circ} 22^{\prime} \mathrm{W}$., at elevations between 2370 and $2530 \mathrm{~m}$.

Winter precipitation (water-equivalent) averages about $150 \mathrm{~mm}$, with occasional years as high as $250 \mathrm{~mm}$. Mean $2 \mathrm{~m}$ wind speed during drifting was $12 \mathrm{~m} / \mathrm{s}$, measured over the $1970-7 \mathrm{I}$ winter, with other weather and site conditions similar to those described for the horizontal-slat fences (Tabler and Schmidt, 1973).

\section{Measurements}

Snow depths were measured directly with an aluminum probe at $3 \mathrm{~m}$ intervals along transects parallel with the prevailing wind. Snow profiles were also measured normal to fences used for a study to determine effect of wind orientation. All other fences were oriented within $15^{\circ}$ of perpendicular to the wind. Snow densities were also sampled at $3 \mathrm{~m}$ intervals, using a standard Federal (Mount Rose) snow tube. In most years, only three to six such transects were needed to characterize snow density adequately.

Transects were located no closer than ${ }_{15} H$ from the ends of the fences to avoid the curved part of the drift caused by wind sweeping around fence ends (Tabler, 1974). The number of transects measured at each fence varied from one to three, depending on the uniformity of the drift and the underlying ground surface.

For horizontal-slat fences, measurements were repeated annually from I971 to I979 at the same locations at each fence where possible. Measurements at vertical-slat fences could only be repeated over two to three years before the fences were moved to new locations whose positions were dictated by the objectives of other studies.

Although in some years measurements were repeated after each significant drifting event throughout the winter, measurements usually began with the arrival of above-freezing temperatures in February or March and were repeated after subsequent drifting events until it was certain that maximum accumulation had been reached for the season. These repetitious measurements allowed equilibrium conditions to be identified when snow accumulation did not increase over one or more major drifting periods.

The number of fences measured varied from year to year, depending on time available for measurements and objectives of other studies in progress. 
During the years when the vertical-slat fences were studied (I962 to I970) we did not regard the up-wind drift as a significant feature, and so failed to take sufficient measurements to characterize the up-wind drifts at equilibrium.

\section{DRIFT GEOMETRY (LONGITUDINAL) \\ Equilibrium drifts}

It is reasonable to assume that any given snow fence has a maximum snow-retention capacity which cannot be exceeded regardless of the quantity of blowing snow arriving at the fence. The snow-drift formed by a fence that has reached this ultimate condition is said to be at "saturation" or "equilibrium". The latter term is used in this paper to avoid possible confusion with free-water content of the drift.

If development of a snow-drift follows the so-called law of natural growth, so that at any given time growth rate is inversely proportional to total accumulation up to that time, then trapping efficiency of the fence might be expected to decline in some manner as the fence fills with snow. If so, the true "equilibrium" profile may be approached as a limit, but may not be attained with a finite amount of snow transport.

Although there is no way to be certain that true equilibrium has indeed been attained for any particular fence in the field, the primary criterion used for this study was cessation of drift growth before the drifting season ended. Where possible, values thus assumed to represent equilibrium conditions were further substantiated when essentially identical profiles were measured behind the same fence over two or more years having different quantities of snow transport.

During the 18 years of study summarized in this paper, equilibrium drifts were measured at 18 horizontal-slat fences, and 14 vertical-slat fences. Dimensions for these drifts are presented in Table I, and empirical relationships derived from the data are summarized in Table II. For comparison, results published by other investigators are given in Table III.

If drifts are geometrically scaled with fence height $H$, then all drift dimensions must be proportional to $H$, so that

$$
y / H=\mathrm{f}(x / H),
$$

where $y$ is drift depth at distance $x$ from the fence. Drift length $L$, maximum depth $y_{\max }$, and cross-sectional area $A$ would therefore be given by

$$
\begin{aligned}
L & =k_{\mathrm{I}} H, \\
y_{\max } & =k_{2} H, \\
A & =k_{3} H^{2} .
\end{aligned}
$$

The equilibrium profiles plotted in Figures $\mathrm{I}$ and 2 indicate the requirement of Equation ( $\mathrm{I})$ is met, and the regressions in Table II imply that (2a), (2b), and (2c) are valid. The equilibrium drifts may therefore be considered geometrically scaled over the range of heights for which data are available.

A polynomial regression curve (Fig. I) for the horizontal-slat fence lee drift, using data from the $2.44,3.17$, and $3.78 \mathrm{~m}$ heights, is

$$
\begin{aligned}
y / H=0.20+0.377(x / H)-0.0472(x / H)^{2}+0.002329(x / H)^{3}- \\
-5.392 \times 10^{-5}(x / H)^{4}+4.840 \times \mathrm{IO}^{-7}(x / H)^{5} ; \quad x / H<30 .
\end{aligned}
$$

This was the lowest degree of polynomial that provided a reasonable fit to the data.

The curve (Fig. 2) approximating the profile of the lee drift for the vertical-slat fences is

$$
\begin{aligned}
y / H=0.13+0.402(x / H)-0.0602(x / H)^{2}+0.00369 \mathrm{r}(x / H)^{3}- & \\
& -1.0854 \times \mathrm{ro}^{-4}(x / H)^{4}+1.2498 \times \mathrm{IO}^{-6}(x / H)^{5} ; \quad x / H<26.5 .
\end{aligned}
$$

Only data for the $1.37 \mathrm{~m}$ height were used in determining regression equation ( $3 \mathrm{~b})$. This was because depth measurements behind the $0.76 \mathrm{~m}$ fence were subject to substantial errors 


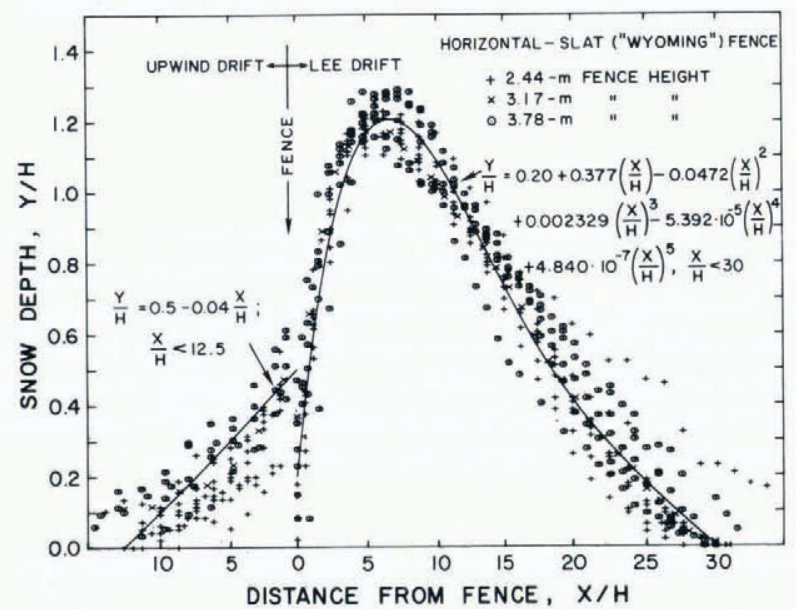

Fig. I. Profiles of equilibrium drifts formed by horizontal-slat, $50 \%$ porous snow fences on level terrain.

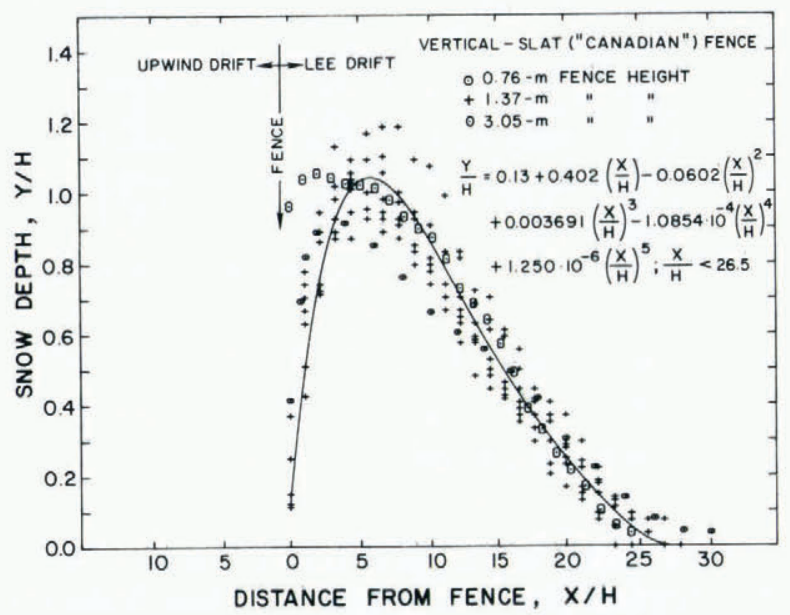

Fig. 2. Profiles of equilibrium lee drifts formed by vertical-slat, $60 \%$ porous snow fences on level terrain.

because irregularities of the underlying ground were significant relative to the height of the fence. Also, the $3.05 \mathrm{~m}$ fence was nearly buried due to several drifting events having winds of opposite direction from the prevailing winds, thus making the drift shape near the fence atypical.

Price (I96I) suggested (based on the observation of Chorley (1959) that a lemniscate equation can be used to describe streamlined forms) that the shape of snow-drifts could be mathematically represented by the "rose" equation (in polar coordinates)

$$
r=(L-l) \cos \eta \theta \quad\left(o<\eta \theta<90^{\circ}\right),
$$

where $r$ is the vector distance from the down-wind end of the drift, $L$ and $l$ are distances from the fence to the leeward and windward ends of the drift, respectively, and $\eta$ is given by

$$
\eta=\frac{\pi(L-l)^{2}}{8 A},
$$


where $A$ is cross-sectional area of the drift. Tabler (1974) has shown that the lemniscate equation

where

$$
r^{2}=L^{2} \cos \eta \theta \quad\left(0<\eta \theta<90^{\circ}\right)
$$

$$
\eta=L^{2} /(2 A)
$$

provided a better fit to lee drifts formed by horizontal-slat fences. Neither Equations (4) nor (5) adequately represent shapes of the equilibrium drifts shown in Figures I and 2, but the empirical polynomial Equations (3) provide adequate approximations.

From Figures $\mathrm{I}$ and 2 and Table I, maximum lee-drift depth is seen to be about $\mathrm{I} .2 \mathrm{OH}$ at $6.7 \mathrm{H}$ distance for horizontal-slat, and $\mathrm{1} .06 \mathrm{H}$ at $5.7 \mathrm{H}$ distance for vertical-slat fences. This difference may be due to the $15^{\circ}$ leeward inclination of the Wyoming design. Drift length is

\begin{tabular}{|c|c|c|c|c|c|}
\hline Fence type & $\begin{array}{l}\text { Height } \\
\mathrm{m}\end{array}$ & $\begin{array}{c}\text { Cross-sectional } \\
\text { area } \\
\mathrm{m}^{2}\end{array}$ & $\begin{array}{c}\text { Drift } \\
\text { length } \\
\mathrm{m}\end{array}$ & $\begin{array}{c}\text { Maximum } \\
\text { depth } \\
\mathrm{m}\end{array}$ & $\begin{array}{l}\text { Number of } \\
\text { fences used } \\
\text { for analyses }\end{array}$ \\
\hline \multicolumn{6}{|l|}{ Lee drift } \\
\hline $\begin{array}{r}\text { Horizontal slat } \\
\text { ("Wyoming") }\end{array}$ & $\begin{array}{l}2.44 \\
3.17 \\
3.78\end{array}$ & $\begin{array}{l}113.6 \pm 7.4 \\
194.1 \\
280.9 \pm 24.6\end{array}$ & $\begin{array}{l}71.9 \pm 6.0 \\
94.5 \\
110.9 \pm 5.0\end{array}$ & $\begin{array}{l}2.90 \pm 0.05 \\
3.84 \\
4.62 \pm 0.11\end{array}$ & $\begin{array}{r}10 \\
1 \\
7\end{array}$ \\
\hline $\begin{array}{l}\text { Vertical slat } \\
\text { ("Canadian") }\end{array}$ & $\begin{array}{l}0.76 \\
1.37 \\
3.00\end{array}$ & $\begin{array}{r}8.4 \pm 0.8 \\
27.7 \pm 1.2 \\
144.7\end{array}$ & $\begin{array}{l}22.2 \pm 6.2 \\
36.2 \pm 1.4 \\
76.2\end{array}$ & $\begin{array}{l}0.73 \pm 0.04 \\
1.46 \pm 0.08 \\
3.16\end{array}$ & $\begin{array}{c}I^{*} \\
12 \\
1\end{array}$ \\
\hline "Swedish" & 1. 98 & $50.0 \pm 5.0$ & $44.6 \pm 8.7$ & $2.15 \pm 0.14$ & 4 \\
\hline \multicolumn{6}{|l|}{$U p$-wind drift } \\
\hline $\begin{array}{r}\text { Horizontal slat } \\
\text { ("Wyoming") }\end{array}$ & $\begin{array}{l}2.44 \\
3.17 \\
3.78\end{array}$ & $\begin{array}{l}13.6 \pm 3.3 \\
34.0 \\
46.3 \pm 14.3\end{array}$ & $\begin{array}{l}27.5 \pm 3.3 \\
38.1 \\
4^{8.5} \pm \mathbf{1} 1.7\end{array}$ & $\begin{array}{l}1.07 \pm 0.16 \\
1.55 \\
2.01 \pm 0.3^{8}\end{array}$ & $\begin{array}{r}10 \\
1 \\
5\end{array}$ \\
\hline
\end{tabular}
$29.5 \mathrm{H}$ for the horizontal-slat and $26.5 \mathrm{H}$ for the vertical-slat fence.

* Confidence intervals from measurements on seven dates.

Average tail slope of the drifts, as measured between down-wind distances of $12 H$ and $22 \mathrm{H}$, is about $6 \%$ for both types of fence (Table II). This slope is the same as that of the halfangle generally recognized as the threshold for separation of flow through two-dimensional divergent channels (diffusers) (Chang, r970), and apparently reflects the pressure gradient required to maintain a uniform longitudinal distribution of surface shear stress.

Cross-sectional area is shown as a function of fence height in Figure 3, which also shows measurements of four "Swedish" fences of the design described by Pugh (1950, p. 5). Areas of lee drifts are approximated by

Horizontal-slat fences:

$$
\begin{aligned}
& A_{\text {lee }}=\mathrm{r} 9.3 H^{2}, \\
& A_{\text {lee }}=\mathrm{I} 4.5 H^{2} .
\end{aligned}
$$

Drifts on the up-wind side of horizontal-slat fences had a maximum depth of about $0.5 H$, and a length of $12 H$. Cross-sectional area is approximately

$$
A_{\mathrm{up}}=2.6 \mathrm{H}^{2} \text {. }
$$

Although the results presented here suggest larger dimensions than previously reported by most investigators (Table III), there is notable agreement with the single example for a $2 \mathrm{~m}$ fence given by Komarov (1954[b]) and Dyunin and Komarov (1954). 
TABLE II. SUMmaRY OF EMPIRICAL EXPRESSIONS DESCRIBING DIMENSIONS OF EQUILIBRIUM DRIFTS

Profile feature

Profile equation

Cross-section, $A$

Water-equivalent volume, $q\left(\mathrm{~m}^{3} / \mathrm{m}\right)$

Mean snow density, $\rho\left(\mathrm{kg} / \mathrm{m}^{3}\right)$

Length, $L$

Maximum depth, $y_{\max }$

Location of $y_{\max }$

Average tail slope $12 H$ to $22 H$
Vertical-slat ("Canadian")
Lee drift

Up-wind drift

$\frac{y}{H}=0.13+0.402\left(\frac{x}{H}\right)-$

$-0.0602\left(\frac{x}{H}\right)^{2}+$

$+0.003691\left(\frac{x}{H}\right)^{3}-$

$-1.0854 \times 10^{-4}\left(\frac{x}{H}\right)^{4}+$

$+1.2495 \times 10^{-6}\left(\frac{x}{H}\right)^{5}$

$2.6 \mathrm{H}^{2}$

$0.9 H^{2.18}$

$14.5 H^{2}$

5. $1 H^{2.18}$

$35^{2} H^{0.18}$

$26.5 H$

I. $06 \mathrm{H}$

$5.7 \mathrm{H}$

$5.8 \%$

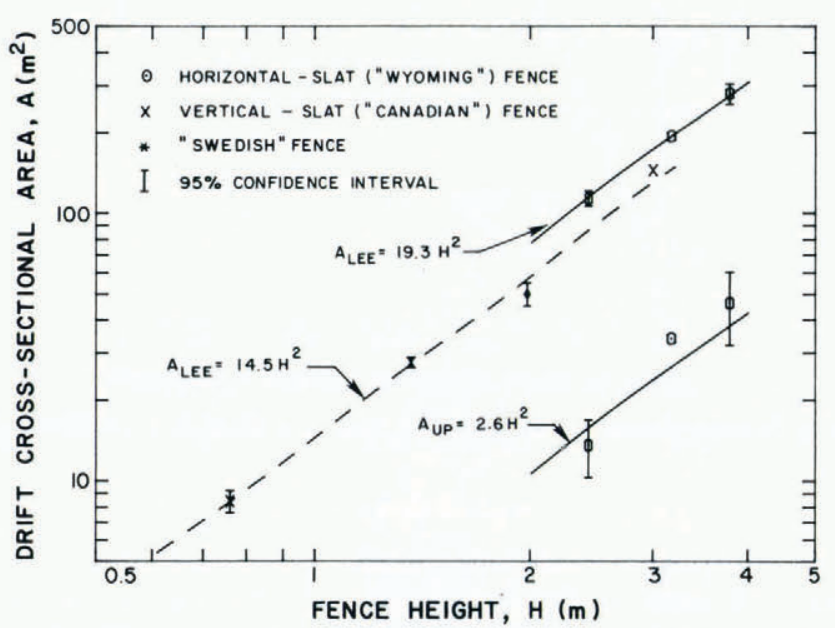

Fig. 3. Cross-sectional area of equilibrium drifts as a function of fence height, for data in Table I.

\section{Pre-equilibrium drifts}

In this section, dimensions of drifts before equilibrium is attained are expressed as functions of "relative drift area" $S$ defined as the ratio of cross-sectional area of a drift to that expected at equilibrium. Pre-equilibrium geometry will only be analyzed for the horizontal-slat fences which provide a better range of heights and more definitive equilibrium values. Polynomial regression equations have been fitted to the pre-equilibrium data for those relationships where they provide reasonable approximations to trends. These empirical equations are not valid beyond the range of data shown in the figures. 
TABLE III. SUMMARY OF LEE-DRIFT DIMENSIONS REPORTED IN LITERATURE FOR $50 \%$ POROUS FENCES WITH HEIGHT $H$

\begin{tabular}{|c|c|c|}
\hline Author & $\begin{array}{c}\text { Cross-sectional area } A \\
\mathrm{~m}^{2}\end{array}$ & $\begin{array}{c}\text { Total length } L \\
\mathrm{~m}\end{array}$ \\
\hline Croce (Mellor, 1965) & $17.8 \mathrm{H}$ & $\mathrm{II}+{ }_{5} \mathrm{H}$ \\
\hline Finney (1934) & & $k_{1} H, k_{1}=13^{-16.5}$ \\
\hline Hogbin $(1970)$ & & $k_{1} H, k_{1}=18-23$ \\
\hline $\begin{array}{l}\text { Komarov (1954[b]); } \\
\text { Dyunin and Komarov (1954) }\end{array}$ & $k_{3} H^{2}, k_{3}=20^{*}$ & $28 H^{*}$ \\
\hline $\begin{array}{l}\text { Nøkkentved (Pugh, 1950) } \\
\text { Price (106r) }\end{array}$ & $\begin{array}{c}k_{3} H^{2}, k_{3}=16.6-18.4 \\
21 H\end{array}$ & $\begin{array}{c}25 H \\
22.1+6.5 H\end{array}$ \\
\hline \multicolumn{3}{|l|}{ Present study: } \\
\hline $\begin{array}{l}\text { Horizontal-slats } \\
\text { Vertical-slats }\end{array}$ & $\begin{array}{l}19.3 H^{2} \\
14.5 H^{2}\end{array}$ & $\begin{array}{l}29.5^{H} \\
26.5 H\end{array}$ \\
\hline
\end{tabular}

* Assumes a $2 \mathrm{~m}$ fence height for the single example given in these references. Area of up-wind drift $=3 \cdot 3 \mathrm{H}^{2}$.

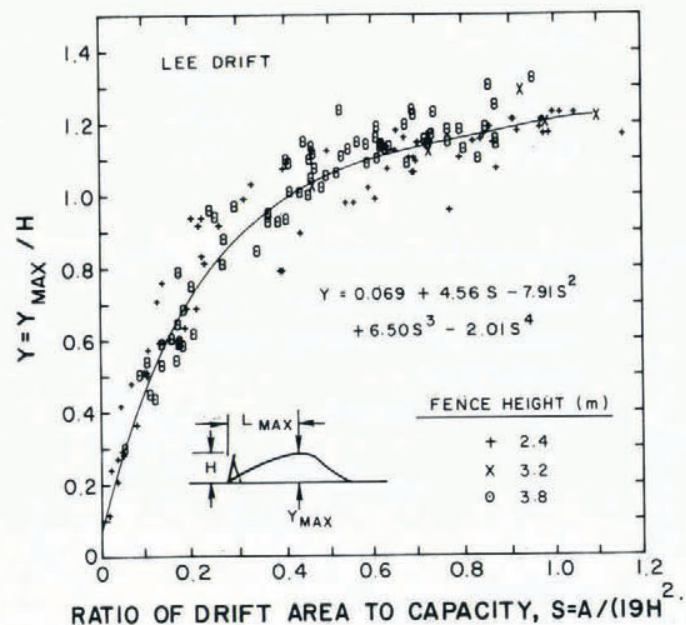

Fig. 4. Maximum depth of lee drifts formed by horizontal-slat fences as a function of cross-sectional area relative to that at equilibrium.

Maximum depth, location of maximum depth, and length of the lee drift are shown as functions of relative drift area in Figures 4 to 6 . These presentations provide estimates of critical drift dimensions prior to equilibrium, and provide insight into how drifts grow. When a $3.8 \mathrm{~m}$ fence is half-filled to capacity $(S=0.5)$, for example, maximum depth of the lee drift would be approximately $1.05 \mathrm{H}$ at about $6.5 \mathrm{H}$ from the fence, and total drift length would be about $\mathrm{i} 6 \mathrm{H}$. Estimates for drift length prior to saturation are essential when it is necessary to place a tall fence, which is not expected to fill, as close to the protected area as possible.

The relatively slow growth in drift length up to $S=0.5$ in Figure 6, coincides with the period of time the steep "slip face", or cornice, dominates the geometry. It is possible that relationships such as those shown in Figures 4 to 6 can be used to deduce changes in trapping efficiency.

Growth of the up-wind drift relative to that of the lee drift is shown in Figure 7. This relationship suggests that up-wind drift area is about $13 \%$ of that of the lee drift throughout the pre-equilibrium period. There is also some indication that the area of the windward 


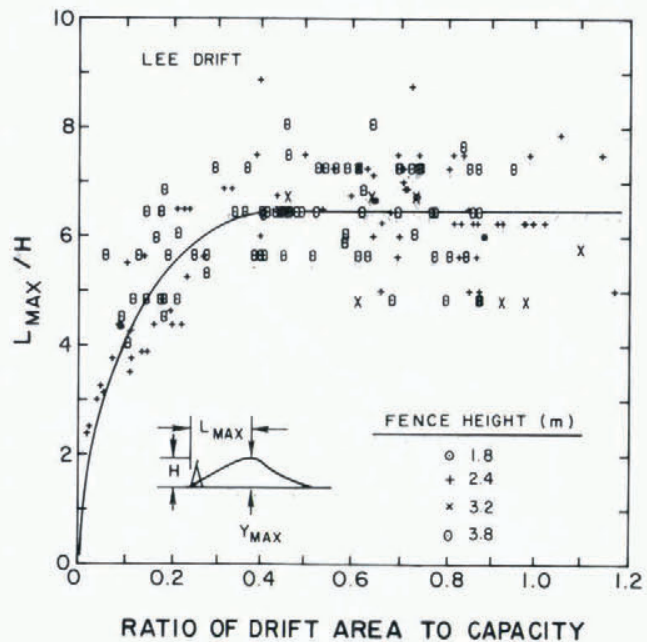

Fig. 5. Location of maximum depth of lee drifts formed by horizontal-slat fences as a function of cross-sectional area relative to that at equilibrium.

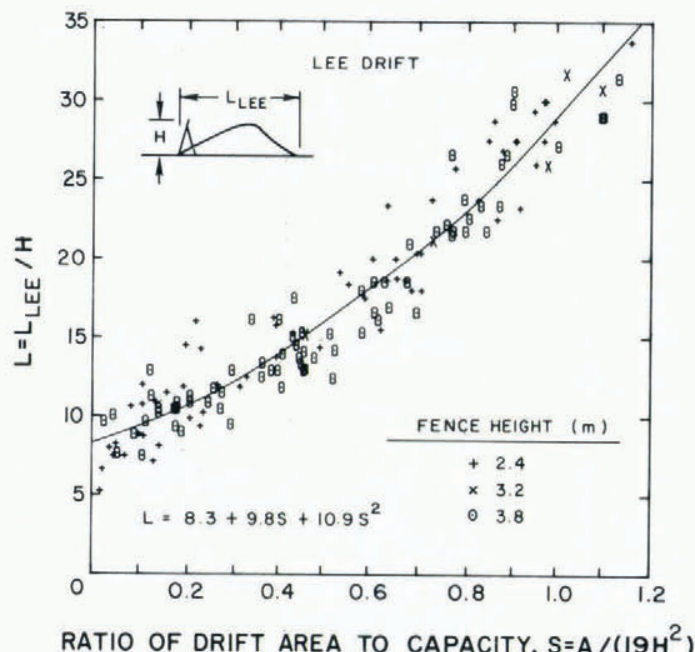

Fig. 6. Length of lee drift formed by horizontal-slat fences as a function of cross-sectional area relative to that at equilibrium.

drift attains a maximum value of about ${ }_{3} \mathrm{H}^{2}$, even though the lee drift may continue to grow due to a terrain depression or an interaction with another row of fencing down-wind.

Maximum depth of the up-wind drift with respect to that of the lee drift, is shown in Figure 8. This relationship suggests that maximum depth of the up-wind drift increases rapidly once the lee drift depth exceeds the height of the fence.

Geometry near fence ends

Criteria for overlapping staggered fences, extension required beyond the protected area, and minimum length must be developed from a knowledge of how capacity of a snow fence varies as a function of distance from the end of the fence. For a fence oriented exactly normal to the wind, ends of the lee drift are rounded by wind sweeping around the fence. This effect 


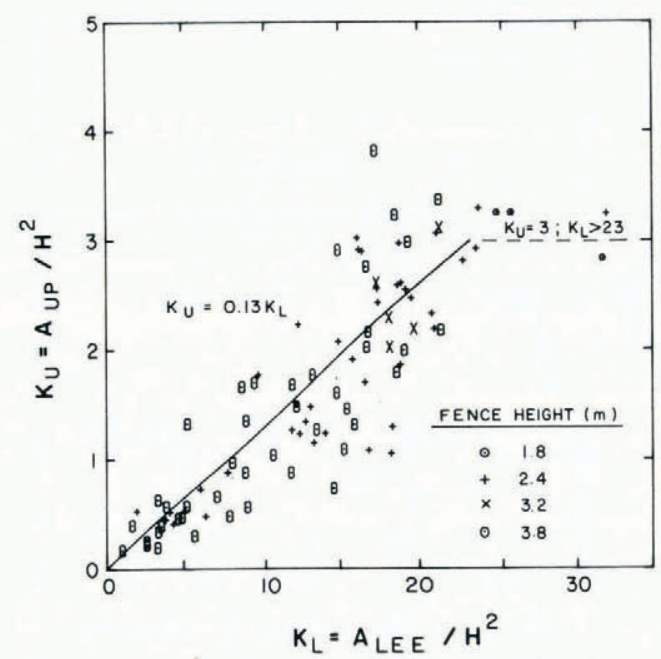

Fig. 7. Cross-sectional area of up-wind drift $A_{\mathrm{up}}$ as a function of lee drift area $A_{1 \mathrm{le}}$, for horizontal-slat fences. Areas are made dimensionless by dividing by the square of fence height $\mathrm{H}^{2}$.

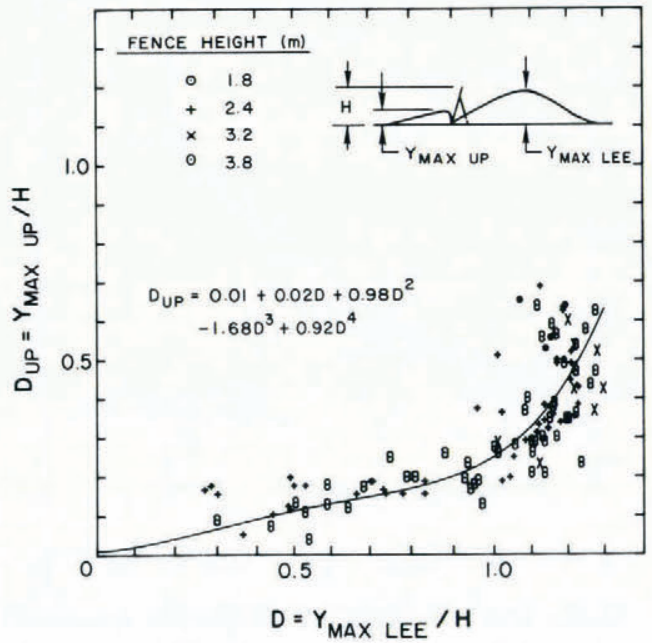

Fig. 8. Maximum depth of up-wind drift as a function of lee-drift depth for horizontal-slat fences.

is due to turbulence generated at the fence boundary, an acceleration of air flow around the ends of the fence, and the response of air flow to lateral pressure gradients developed behind the barrier.

Data for 6 horizontal-slat fences show this end-effect on cross-sectional area to extend inward as far as $1_{2} \mathrm{H}$ from the end of the fence (Fig. 9). Drift length varies with distance from the fence end as shown in Figure ro.

\section{Effect of wind orientation}

The effect of fence orientation (i.e. wind attack angle) on drift geometry is important in determining to what degree fences can be skewed with respect to prevailing wind direction. 


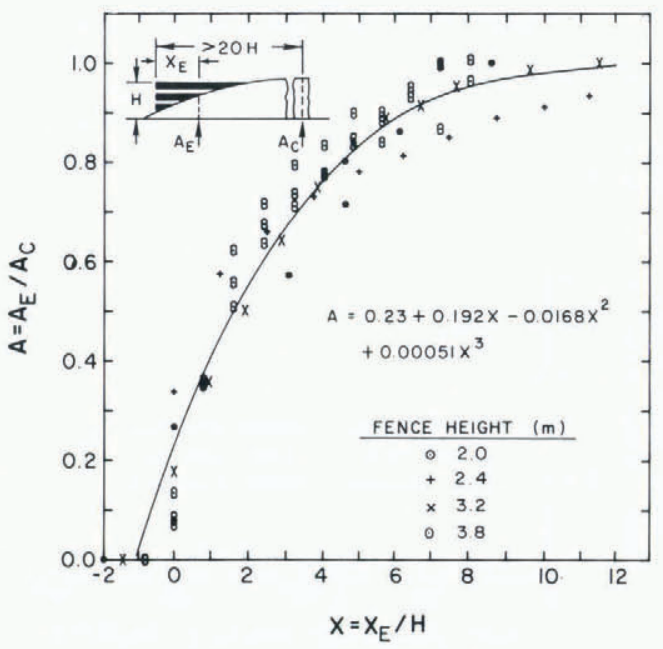

Fig. 9. Relative cross-sectional area of lee drift as a function of distance from end of horizontal-slat fences.

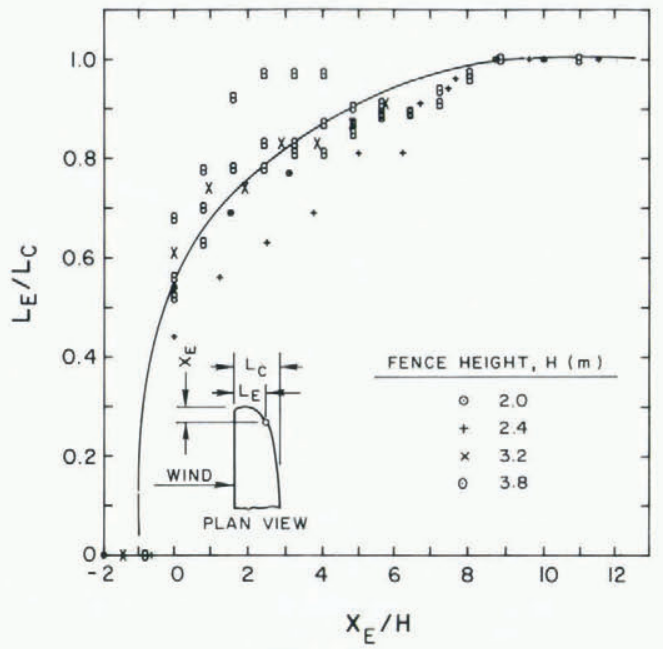

Fig. 10. Relative length of lee drift as a function of distance from end of horizontal-slat fences.

The limited data shown in Figure I I suggest that cross-sectional area of a lee drift, as measured perpendicular to the fence, varies directly as the cosine of the wind departure angle. This implies that geometry of a lee drift, as measured parallel to the wind, is independent of fence orientation up to departure angles of at least $75^{\circ}$. This generalization only applies to very long fences (the fences used for these measurements had lengths of $50 H$ to $200 H$ ), and does not necessarily imply that trapping efficiency is unaffected by wind orientation.

\section{DENSITY OF SNOW-DRIFTS}

The mean vertical snow densities shown in Figure 12, represent only those measurements taken during the accumulation season, before the beginning of melt. At the locations used in this study, melt is usually negligible over the drifting season, so that densification is due 


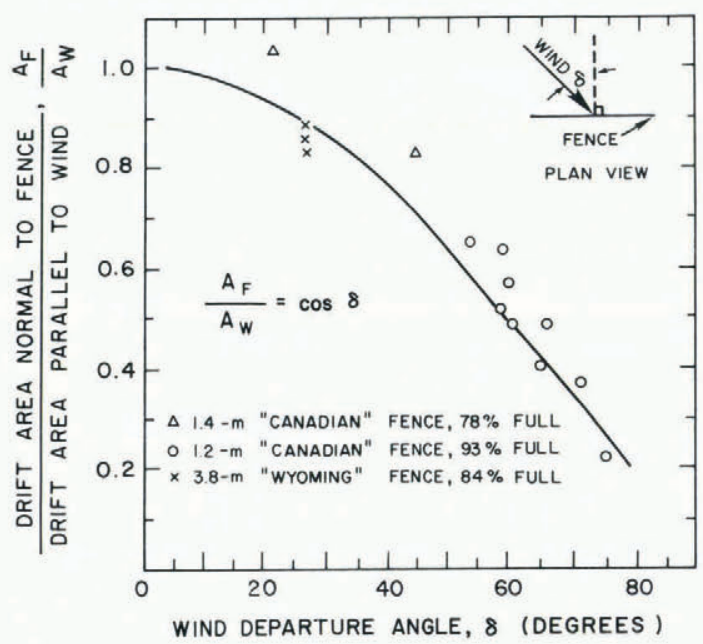

Fig. II. Relative area of lee drift as a function of wind-departure angle. Drift area parallel to wind $A_{\mathrm{w}}$ was measured behind fences oriented perpendicular to the prevailing wind.

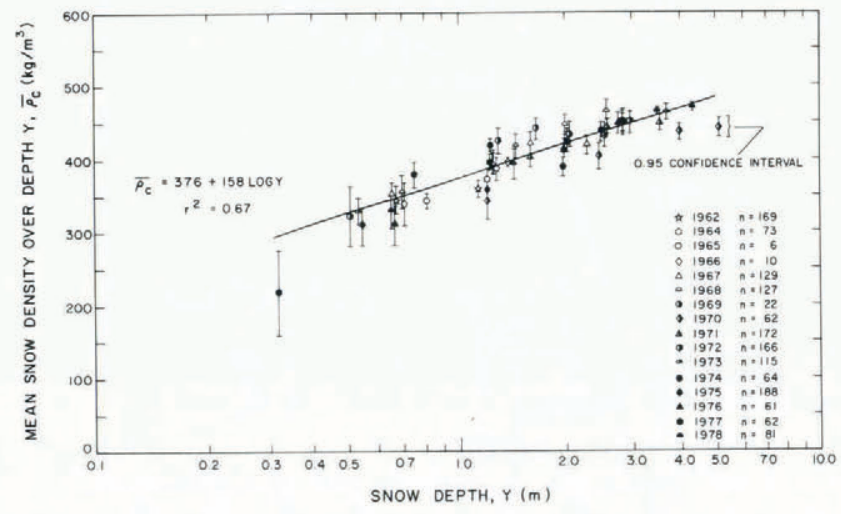

Fig. 12. Average (vertical) snow density as a function of snow depth for drifts before melt. Density was measured with a Federal sampler and corrected for overestimation.

primarily to compressive loading by the overlying snow. As a result, the depth-density relationship is relatively consistent from year to year.

Because it is generally recognized that the Federal (Mount Rose) snow sampler tends to overestimate density, the measured values were corrected using a modification of the empirical equation developed by Peterson and Brown (1975):

$$
\rho_{\mathrm{c}}=\rho_{\mathrm{m}}\left(\mathrm{r} . \mathrm{IO}-0.0004 \rho_{\mathrm{m}}\right) \text {, }
$$

where $\rho_{\mathrm{m}}$ is measured snow density (in $\mathrm{kg} / \mathrm{m}^{3}$ ), and $\rho_{\mathrm{c}}$ is the corrected density. The correction is thus $2 \%$ at $300 \mathrm{~kg} / \mathrm{m}^{3}$ and $10 \%$ at $500 \mathrm{~kg} / \mathrm{m}^{3}$.

An average curve fitted to all years of data for snow depths $y$ is

$$
\bar{\rho}_{\mathrm{c}}=376+\mathrm{r} 5^{8} \log y ; \quad 0.5<y<5 \quad(r=0.82) .
$$

In general, densities predicted by Equation (9) for depths to $5 \mathrm{~m}$ are within $10 \%$ of published values for polar and alpine snow, as summarized by Keeler (1969). Although 
validity of this regression equation is strictly limited to the range of depths used for its development, values predicted for depths between 20 and $100 \mathrm{~m}$ are also within $10 \%$ of those reported for deep cores from interior Greenland (Langway, cited by Benson (1962); Miller, unpublished). Equation (9) closely coincides with values expected for the lower limit of the "soaked" glacier facies, as typified by Greenland Station 0-35 (Benson, 1962).

Storage capacities of snow fences must be expressed in terms of water-equivalent if they are to be comparable with mass transport estimates used for designing snow-fence systems. Snow-drift water-equivalent volume $q$, expressed in $\mathrm{m}^{3}$ per meter of fence length, is given by

$$
q=\frac{\mathrm{I}}{\rho_{\mathrm{w}}} \int_{0}^{L} \rho_{\mathrm{c}} y \mathrm{~d} x,
$$

where $\rho_{\mathrm{w}}$ is the density of water, $y$ is snow depth, and $x$ is distance from the fence. Numerical integration of Equation (Io) for fence heights to $5 \mathrm{~m}$, after substituting expressions for $\rho_{\mathrm{c}}$ (Equation (9)) and $y$, from the profile Equations (3), give the approximations

horizontal-slat fences:

$$
\begin{aligned}
& q_{\text {lee }}=6.9 H^{2.18}, \\
& q_{\text {lee }}=5.1 H^{2.18},
\end{aligned}
$$

where $q_{\text {lee }}$ is water-equivalent volume of the lee drift (in $\mathrm{m}^{3} / \mathrm{m}$ ), and $H$ is in meters.

A similarly derived approximation for water-equivalent volume of the drift on the up-wind side of horizontal-slat fences is

$$
q_{\mathrm{up}}=0.9 H^{2.18} \text {. }
$$

The mean snow density for drifts is given by

$$
\bar{\rho}=\frac{\rho_{\mathrm{w}} q}{A} .
$$

Substituting Equations (6) and (I I) into (I3), mean snow density for lee drifts can be approximated by

horizontal-slat fences:

$$
\begin{aligned}
& \bar{\rho}=35^{8} H^{0.18}, \\
& \bar{\rho}=35^{2} H^{0.18} .
\end{aligned}
$$

\section{Discussions AND CONGLUSIONS}

Results reported here are restricted to snow fences having $50 \%$ porosity located on nearly level surfaces, and future studies will be needed to develop methods for predicting drift geometry in irregular terrain.

As a general rule over the commonly used range of fence heights, lee-drift geometry is characterized by length proportional to fence height $H$ and cross-sectional area proportional to $H^{2}$. Water-equivalent volume, however, is approximately proportional to $H^{2.18}$ due to the increase in densification with snow depth. This suggests an even greater economic advantage of tall fences than was indicated from an analysis based on cross-sectional area (Tabler, 1974).

These results imply that equilibrium drifts are geometrically scaled with height over the range 0.8 to $4 \mathrm{~m}$. In another paper (Tabler, 1980), the author has shown from outdoor modeling studies on lake ice that the relationship extends to heights as low as $0.06 \mathrm{~m}$, and hypothesizes that dynamic similarity requirements are satisfied over a period of time because surface roughness height $z_{0}$ varies approximately as the square of shear velocity $u_{*}$ in saltating flows in air.

The relatively limited data for vertical-slat fences do not allow as much confidence to be placed in the results for this design. In comparison with the Wyoming horizontal-slat fences, 
however, it appears that drifts behind vertical-slat Canadian fences tend to be about $10 \%$ shorter and $12 \%$ shallower, resulting in $26 \%$ less water-equivalent volume. It is uncertain how much of this difference is due to the $15^{\circ}$ inclination of the Wyoming design as compared to differences in porosity and dimensions and orientation of the slats.

As mentioned previously, there is no way to be certain that the drifts considered to be at equilibrium are actually the maximum drifts possible for the fence designs studied here. The author noted in an earlier paper (Tabler, 1974) that drifts behind the Wyoming fence appeared to have a cross-sectional area of $18 \mathrm{H}^{2}$ and a length of $24 \mathrm{H}$, based on two years of measurements. A comparison with the new estimates after eight years of study demonstrates that, although future observations may also lead to upward revisions of maximum dimensions, it seems unlikely that ultimate estimates would depart significantly from those presented here.

\section{Acknowledgements}

Research reported here was supported in part by the Wyoming State Highway Department. The author gratefully acknowledges the invaluable assistance of research technician Robert L. Jairell in the collection of data over the last 16 years of this study.

\section{REFERENCES}

Benson, C. S. 1962. Stratigraphic studies in the snow and firn of the Greenland ice sheet. U.S. Cold Regions Research and Engineering Laboratory. Research Report 70.

Chang, P. K. 1970. Separation of flow. New York, Pergamon Press. (International Series of Monographs in Interdisciplinary and Advanced Topics in Science and Engineering, Vol. 3.)

Chorley, R. J. 1959. The shape of drumlins. Fournal of Glaciology, Vol. 3, No. 25, p. 339-44.

Dyunin, A. K., and Komarov, A. A. I 954. O konstruktsii snegovykh shchitov [On the construction of snow fences]. Trudy Transportno-Energeticheskogo Instituta, Tom 4, p. I I I-18. [English translation: Canada. National Research Council. Technical Translation 1103 , 1964.]

Finney, E. A. 1934. Snow control on the highways. Bulletin. Michigan Engineering Experiment Station (East Lansing), No. 57.

Hogbin, L. E. 1970. Snow fences. G.B. Road Research Laboratory. Report (Crowthorne, Berkshire) No. LR 362.

Keeler, C. M. r 969 . Some physical properties of alpine snow. U.S. Cold Regions Research and Engineering Laboratory. Research Report 271.

Komarov, A. A. I954[a]. Nektoryye zakonomernosti perenosa i otlozheniya snega v rayonakh Zapadnoy Sibiri i ikh ispol'zovaniye v snegozaderzhanii i snegobor'be [Some rules on the migration and deposition of snow in Western Siberia and their application to control measures]. Trudy Transportno-Energeticheskogo Instituta, Tom 4, p. 89-97. [English translation: Canada. National Research Council. Technical Translation I094, 1963.]

Komarov, A. A. I954[b]. Puti povysheniya effektivnosti raboty snegozashchitnykh zaborov i shchitov [Ways of increasing the efficiency of snow fences]. Trudy Transportno-Energeticheskogo Instituta, Tom 4, p. I19-26. [English translation: Canada. National Research Council. Technical Translation 1095, 1963.]

Mellor, M. 1965. Blowing snow. U.S. Cold Regions Research and Engineering Laboratory. Cold regions science and engineering. Hanover, N.H., Pt. III, Sect. A3c.

Miller, K. J. Unpublished. The physical properties and fabrics of two $400 \mathrm{~m}$ deep ice cores from interior Greenland. [M.A. thesis, State University of New York at Buffalo, 1978.]

Peterson, N. R., and Brown, A. J. I 975 . Accuracy of snow measurements. Proceedings of the Western Snow Conference, 43 rd annual meeting, p. $1-5$.

Price, W. I. J. 1961. The effect of the characteristics of snow fences on the quantity and shape of deposited snow. Union Géodésique et Géophysique Internationale. Association Internationale d'Hydrologie Scientifique. Assemblée générale de Helsinki, 25-7-6-8 1960. Commission des Neiges et Glaces, p. 89-98. (Publication No. 54 de l'Association Internationale d'Hydrologie Scientifique.)

Pugh, H. L. D. 1950. Snow fences. G.B. Road Research Laboratory. Road Research Technical Paper No. 19.

Schneider, T. R. I959. Schneeverwehungen und Winterglätte. Interner Bericht des Eidg. Institutes für Schnee- und Lawinenforschung, Nr. 302. [English translation: Canada. National Research Council. Technical Translation 1038, I 962.$]$

Tabler, R. D. [1973.] New snow fence design controls drifts, improves visibility, reduces road ice. Proceedings of the 46th Annual Transportation Engineering Conference, University of Colorado, February 22-23, 1973, p. $16-27$.

Tabler, R. D. 1974. New engineering criteria for snow fence systems. Transportation Research Record (Washington, D.C.), 506, p. $65-78$.

Tabler, R. D. 1975. Estimating the transport and evaporation of blowing snow. Great Plains Agricultural Council. Research Committee. Publication No. 73, p. 85-104. 
Tabler, R. D. 1980. Self-similarity of wind profiles in blowing snow allows outdoor modeling. Fournal of Glaciology, Vol. 26, No. 94, p. 42 I-34.

Tabler, R. D. Unpublished. Evaluation of the first-year performance of the Interstate-8o snow fence system. Final Report on Contract 16-247-CA. [Prepared for Wyoming Highway Dept. by Rocky Mountain Forest and Range Experiment Station, Forest Service, U.S. Dept. of Agriculture; Fort Collins, Colorado, 1972.]

Tabler, R. D., and Schmidt, R. A. 1973. Weather conditions that determine snow transport distances at a site in Wyoming. (In [International Hydrological Decade.] The role of snow and ice in hydrology. Proceedings of the Banff symposia, September 1972. Paris, UNESCO; Geneva, WMO; Budapest, IAHS, Vol. I, p. 1 18-27. (Publication No. 107 de l'Association Internationale d'Hydrologie Scientifique.))

Wuebben, J. L. 1978. A hydraulic model investigation of drifting snow. J.S. Cold Regions Research and Engineering Laboratory. Report 78-16. 